\title{
Chemical Composition and Some Biological Activities of the Methanolic Encephalartos ferox Fruit Extract
}

\author{
Phakamani Hopewell Tsilo ${ }^{1, *}$, Sidney Tsolanku Maliehe', Jabulani Siyabonga Shandu', Rene Khan²
}

Phakamani Hopewell Tsilo ${ }^{1, *}$, Sidney Tsolanku Maliehe', Jabulani Siyabonga Shandu', Rene Khan ${ }^{2}$

'Department of Biochemistry and Microbiology, University of Zululand, KwaDlangezwa 3886, SOUTH AFRICA. ${ }^{2}$ Discipline of Medical Biochemistry, College of Health Sciences, University of KwaZuluNatal, Private Bag X 54001, Durban 4000, SOUTH AFRICA.

\section{Correspondence}

\section{Tsilo Phakamani Hopewell}

Department of Biochemistry and Microbiology, University of Zululand, KwaDlangezwa 3886, SOUTH AFRICA.

E-mail: phakamanitsilo90@gmail.com

History

- Submission Date: 29-04-2020;

- Review completed: 01-06-2020;

- Accepted Date: 04-06-2020

DOI : 10.5530/pj.2020.12.167

Article Available online http://www.phcogj.com/v12/i5

\section{Copyright}

(C) 2020 Phcogi.Com. This is an openaccess article distributed under the terms of the Creative Commons Attribution 4.0 International license.

\section{ABSTRACT}

Background: Although literature reports the therapeutic properties of Encephalartos ferox, there are limited pharmacological studies of its fruit. Objective: This study sought to evaluate the antibacterial, antioxidant, anti-quorum sensing, and in vitro cytotoxic activities of the methanolic E. ferox fruit extract. Methods: The chemical constituent of the methanolic fruit extract was analysed using gas chromatography-mass spectrometry. Antibacterial activity of the extract was investigated against Staphylococcus aureus (ATCC 25923), Bacillus cereus (ATCC 10102), Escherichia coli (ATCC 25922) and Pseudomonas aeruginosa (ATCC 27853) using the broth dilution method. The standard 2.2-diphenyl-1-picrylhydrazyl (DPPH) and 2.2-azinobis (3-ethylbenzothiazoline-6-sulfonic acid) (ABTS) methods were used to evaluate the scavenging activities of the extract. Anti-quorum sensing activity was assessed against biosensor strainChromobacterium violaceum (ATCC 12472). Cytotoxicity in HepG2 cells was investigated using the tetrazolium-based colorimetric (MTT) assay. Results: The extract revealed eight volatile compounds with cis-Vaccenic acid (87.06\%) and 9-Octadecenoic acid, 1,2,3-propanetriyl ester $(5.21 \%)$ as the major components. Antibacterial activity against all tested strains with minimum inhibitory concentration range of $1.56-12.5 \mathrm{mg} / \mathrm{mL}$ was observed. The DPPH and ABTS assays demonstrated scavenging activities with the median inhibitory concentration $\left(I C_{50}\right)$ values of $0.09 \mathrm{mg} / \mathrm{mL}$ and $0.003 \mathrm{mg} / \mathrm{mL}$, respectively. The extract also displayed strong anti-quorum sensing activity with $93 \%$ inhibition of violacein production at $25 \mathrm{mg} / \mathrm{mL}$. A half maximum inhibitory concentration $\left(\mathrm{IC}_{50}\right)$ of $5370 \mu \mathrm{g} / \mathrm{mL}$ was computed in HepG2 cells. Conclusion: The extract has potential to be used as a source of therapeutic compounds in pharmaceutical applications.

Key words: Antibacterial, Anti-quorum sensing, Antioxidant, Cytotoxicity.

\section{INTRODUCTION}

New and re-emerging infections due to pathogenic microorganisms such as viruses, bacteria and fungi still present high mortality and morbidity rates per year, especially in developing countries. ${ }^{1}$ Moreover, despite the big strides in discovery of novel antimicrobial compounds, resistance to antimicrobials by microorganisms is still on the increase. ${ }^{2}$ New resistance mechanisms are emerging globally, threatening the ability to treat common infections. Resistant microorganisms that arise due to mutation tend to grow exponentially and transfer their resistant genes to others. ${ }^{3}$ Major reasons for the increasing prevalence of antimicrobial resistance are inappropriate use of antimicrobials, inadequate antimicrobial dosage, poor quality drugs and excessive use of antimicrobials. ${ }^{4}$ Thus, to confront this challenge, new antimicrobials which are characterised by improved selectivity, potency and less toxicity compared to the existing antimicrobials are highly needed.

Plant-based products are recognized as alternative resources of diverse chemical compounds that display potent biological profiles and pharmacological actions. ${ }^{5}$ According to the World Health Organisation (WHO), more than $80 \%$ of the population in developing countries rely on medicinal plants for therapy. ${ }^{6}$ This is because of their better acceptability with human physiology, costeffectiveness, accessibility and fewer side effects. ${ }^{7}$ Plants' medicinal products are reported to possess a broad spectrum of pharmacological activities such as antioxidant, antimicrobial and anticancer activities without repercussions. ${ }^{8}$ The pronounced pharmacotherapeutic effects are perceived to be due to their diverse bioactive compounds. Among these compounds are alkaloids, saponins, tannins, glycosides and flavonoids. Antimicrobial compounds exert their actions through alteration or disruption of cell membrane structures and inhibition of cell wall, protein and nucleic acid biosynthetic processes. ${ }^{10}$

The pharmacological and physiological potentials of bioactive compounds do also depend on their ability to inhibit quorum sensing among microorganisms. Quorum sensing (QS) is a communication system between microbial cells. ${ }^{11}$ It enables microorganisms to recognise and react to the size of the surrounding population. Gram negative microorganisms produce acyl-homoserine lactones (AHL) as signal molecules for communication. ${ }^{12}$ QS regulates gene expression, production of vital pigments, biofilm formation and other factors that contribute pathogenicity of microorganisms. ${ }^{13} \quad$ Anti-quorum-sensing compounds reduces microbial virulence without inhibiting microbial growth. 
Excess reactive oxygen species (ROS) can damage biomolecules such as nucleic acids (DNA and RNA), lipids, carbohydrates and proteins in the body, leading to homeostatic disruption and various sicknesses. ${ }^{14}$ Plants' secondary metabolites are recognised for their antioxidant properties. ${ }^{15}$ Antioxidants are free radical scavengers. They have the ability to either prevent the generation of ROS directly, scavenge the produced ROS, act as reducing agents or quenchers of singlet oxygen. They exert their effect either by electron donation, gene expression regulation or metal ion chelation. ${ }^{16}$ Antioxidants exhibit a wide range of biological effects that include nucleic acids' protection, anti-aging, antibacterial and anticancer activities. ${ }^{14}$ Polyphenols, carotenoids and vitamin E and $\mathrm{C}$ are the mostly abundant natural antioxidants from plant materials. ${ }^{17}$

Although much attention has been given to plant based products due to their therapeutic properties, there are limited studies focusing on their toxicity levels. ${ }^{11}$ However, it is important to evaluate their toxicity threshold before use for safety reasons. This is because plant-based products may be toxic even in small dosages, leading to adverse effects and even death. ${ }^{18}$

Encephalartos ferox is a cycad belonging to the Zamiaceae family. It is endemic in the northern KwaZulu Natal, South Africa. ${ }^{19}$ The plant parts, especially the leaves are used as prophylaxis for various ailments. Its leaves are used to treat oestrogen-dependent tumours and diabetes. ${ }^{20}$ The leaves have been scientifically proven to possess antidiabetic and antioxidant activities. ${ }^{21}$ However, to our utmost knowledge, there are no studies reporting on the medicinal properties of its fruit. Our study aimed to investigate the antibacterial, anti-quorum sensing, antioxidant activities and in vitro cytotoxicity of E. ferox fruit using standard methods.

\section{MATERIALS AND METHODS}

\section{Chemicals and media}

All the chemicals and media used in this study were of analytical grades and were procured from Sigma Aldrich Co. Ltd (Steinheim, Germany) and Merck (Ltd) Pty.

\section{Microorganisms}

The bacterial strains (Staphylococcus aureus (ATCC 25923), Bacillus cereus (ATCC 10102), Escherichia coli (ATCC 25922) and Pseudomonas aeruginosa (ATCC 27853)) were obtained from the Microbiology Laboratory, University of Zululand, South Africa.

\section{Fruit preparation and extraction}

The healthy fruit (cone) of E. ferox was collected from Manguzi in KwaZulu-Natal $\left(28^{\circ} 45^{\prime} \mathrm{S} 31^{\circ} 544^{\prime} \mathrm{E}\right)$ and transported to the University of Zululand, South Africa. The cone was authenticated by Dr. Ntuli, Department of Botany, University of Zululand, KwaDlangezwa at the University Herbarium. The plant sample was assigned specimen number $\mathrm{VH} 04$ and was deposited at the University herbarium. The fruit was washed in tap water, dried at room temperature and milled to a fine powder. Fruit material $(20 \mathrm{~g})$ was extracted with $200 \mathrm{~mL}$ of methanol. The extract was filtered using Whatman No.1 filter paper before being transferred into pre-weighed glass containers. The solvent was evaporated under a stream of air in a fume hood at room temperature to quantify extraction efficacy.

\section{Phytochemical analysis}

Phytochemistry tests were done to identify the chemical constituents of the plant extracts. Well established methods for qualitative analysis of phytochemicals were used to screen the crude fruit extract. ${ }^{22}$ The volatile components of the methanolic fruit extract was analysed using gas chromatography-mass spectrometry (GC-MS). The GC oven temperature was initially set at $40{ }^{\circ} \mathrm{C}$ for 3 minutes and subsequently raised by $5{ }^{\circ} \mathrm{C}$ per minute to $220^{\circ} \mathrm{C}$. The injector temperature was set at $250{ }^{\circ} \mathrm{C}$, and the flow rate of helium gas was $1.0 \mathrm{~mL}$ per minute, with a 10:1 split ratio. The MS system had an ion source temperature of 250 ${ }^{\circ} \mathrm{C}$ and voltage of $70 \mathrm{eV}^{23}$

\section{Panel of microorganisms}

The extract was evaluated for its antibacterial activity against two Gram positive bacteria: Staphylococcus aureus (ATCC 25923) and Bacillus cereus (ATCC 10102) and two Gram negative bacteria: Escherichia coli (ATCC 25922) and Pseudomonas aeruginosa (ATCC 27853). Prior to the antibacterial activity tests, each of the bacterial strains were resuscitated on nutrient broth and nutrient agar and incubated at $37^{\circ} \mathrm{C}$. The overnight cultures were inoculated with a sterile inoculating loop into glass tubes of sterile saline solution and vortexed. The turbidity of the bacterial suspensions was adjusted to McFarland standard (1.5 X 106 colony forming unit $/ \mathrm{mL}$ ) using a spectrophotometer (SpectroquantPharo 100).

\section{Minimum inhibitory concentration (MIC)}

The MIC of the extract was determined using broth dilution method in a sterile 96-well plate. Mueller-Hinton broth of $100 \mu \mathrm{L}$ was added to each and $100 \mu \mathrm{L}(100 \mathrm{mg} / \mathrm{mL})$ of the fruit extract was added to the first row of the 96-well plate. Serial dilution was performed to vary the concentrations $(50-0.3 \mathrm{mg} / \mathrm{mL})$. About $100 \mu \mathrm{L}$ of the bacterial suspensions were separately pipetted into the wells. Thereafter, the plate was incubated at $37{ }^{\circ} \mathrm{C}$. After overnight incubation, $40 \mu \mathrm{L}$ of p-iodonitrotetrazolium violet $(0.2 \mathrm{mg} / \mathrm{mL})$ was added into each well and incubated at $37^{\circ} \mathrm{C}$ for 30 minutes. The lowest concentration that inhibited bacterial growth was considered as the MIC..$^{24}$

\section{Minimum bactericidal concentration (MBC)}

Bactericidal effect of the extract was evaluated on nutrient agar. Briefly, each well that demonstrated no visible bacterial growth during MIC evaluation were streaked on nutrient agar. Thereafter, the agar plates were incubated at $37{ }^{\circ} \mathrm{C}$ for 24 hours. The lowest concentration to induce a cidal effect on the tested strains was considered as MBC. ${ }^{18}$

\section{Anti-quorum sensing activity}

The effect of the extract on inhibition of violacein production by the biosensor bacterial strain- Chromobacterium violaceum (ATCC 12472) was assessed using Lysogeny broth (LB). An overnight culture of C. violaceum (ATCC 12472), adjusted to McFarland standard (1.5 $\mathrm{X} 10^{6}$ colony forming unit $/ \mathrm{mL}$ ), was pipetted into autoclaved LB (3 $\mathrm{mL})$, containing different concentrations of the extract $(0.39-25 \mathrm{mg} /$ $\mathrm{mL})$. The different mixtures were incubated at $37{ }^{\circ} \mathrm{C}$ for 24 hours. Each mixture $(2 \mathrm{ml})$ was centrifuged $(13,000 \mathrm{rpm}, 15$ minutes $)$ to precipitate violacein. The supernatant was discarded and the pellet was re-suspended in $2 \mathrm{ml}$ of $10 \% \mathrm{DMSO}$ and vortexed. The solutions were centrifuged at 13,000 rpm for 15 minutes. A microplate reader was then used to measure the violacein at the optical density (OD) of $585 \mathrm{~nm}$. C violaceum (ATCC 12472) culture that was not treated with the extract, served as a control. The formula used for the determination of the violacein inhibition was as follows: Violacein inhibition $(\%)=\left(\mathrm{OD}_{585} \mathrm{~mm}\right.$ control $\left.^{-}{ }_{\text {OD } 585 \mathrm{~nm} \text { test }}\right) / \mathrm{OD}_{585 \mathrm{~nm} \text { control }} \times 100 .^{25}$

\section{2,2-diphenyl-1-picrylhydrazyl (DPPH) radical scavenging assay}

The DPPH free radical scavenging activity of the fruit extract was determined in a sterile 96-well plate. ${ }^{26}$ The DPPH $(0.02 \mathrm{mg} / \mathrm{mL})$ was mixed $(1: 1 \mathrm{v} / \mathrm{v})$ with different concentrations of the extract. Each mixture was made to stand for 30 minutes in darkness at room temperature (25 ${ }^{\circ} \mathrm{C}$ ) and the absorbance was read at $517 \mathrm{~nm}$ using microplate reader. The extract without DPPH served as blank while ascorbic acid (AA) and 
butylated hydroxyl anisole (BHA) were used as the positive controls. The percent inhibition of DPPH radical was calculated by the following formula: \% DPPH scavenging activity $=\left[\right.$ Ao $\left.-A_{1} / \mathrm{Ao}\right] \times 100$ where, $\mathrm{A}_{1}$ and Ao equal the absorbance recorded at $517 \mathrm{~nm}$ of the control and the test, respectively. The median inhibitory concentration $\left(\mathrm{IC}_{50}\right)$ of the extract against DPPH was calculated graphically.

\section{2,2'-azino-bis-3-ethylbenzothiazoline-6-sulfonic acid (ABTS) radical scavenging assay}

The ABTS free radical scavenging activity of the fruit extract was investigated using serial dilution method. ${ }^{27}$ ABTS solution $(0,003$ $\mathrm{g} / \mathrm{mL})$ was mixed $(1: 1 \mathrm{v} / \mathrm{v})$ with different concentrations of the fruit extract. The mixtures were made to stand for 15 minutes at $25{ }^{\circ} \mathrm{C}$ and the absorbance was read at $734 \mathrm{~nm}$ using microplate reader. The extract without ABTS solution served as blank. Ascorbic acid (AA) and butylated hydroxyl anisole (BHA) were used as the positive controls. The percent inhibition of ABTS radical was calculated by the following formula: $\%$ ABTS scavenging activity $=\left[\right.$ Ao $\left.-A_{1} / A o\right] \times 100$ where, $A_{1}$ and Ao equal the absorbance recorded at $734 \mathrm{~nm}$ of the control and the test, respectively. The median inhibitory concentration $\left(\mathrm{IC}_{50}\right.$ ) of the extract against ABTS was calculated graphically.

\section{Cytotoxicity assay of the extract}

The cytotoxicity of the extract to human hepatocellular carcinoma (HepG2) cells was investigated using the methylthiazol tetrazolium (MTT) assay. HepG2 were grown to confluency in $25 \mathrm{~cm}^{3}$ flasks using complete culture medium (CCM: EMEM, 10\% foetal calf serum, $1 \%$ L-glutamine, $1 \%$ Penstrep-fungizone). Confluent cells were trypsinized and seeded into a 96-well plate $\left(2 \times 10^{4}\right.$ cells / $200 \mu \mathrm{l}$ CCM / well) in triplicate for each treatment. Cells were allowed to adhere and acclimatise for 24 hours at $37^{\circ} \mathrm{C}$. The CCM was then removed and the treatment extract $(0-10,000 \mu \mathrm{M})$ was added to the wells. After 24 hours treatment, the treatment medium was removed, then $100 \mu \mathrm{l}$ fresh CCM and $20 \mu \mathrm{l}$ of MTT reagent ( $5 \mathrm{mg} / \mathrm{ml}$ in PBS) was added to each well. After $4 \mathrm{~h}$ at $37^{\circ} \mathrm{C}$, the MTT solution was aspirated from the wells and the formazan crystals were solubilized in $100 \mu \mathrm{L}$ of dimethyl sulfoxide (DMSO). The amount of MTT reduction was measured by reading the optical density (OD) of the samples at $570 / 690 \mathrm{~nm}$ using the BioTek $\mu$ Quant microplate reader (USA). The formula used for the evaluation of the cell viability was: Cell viability $(\%)=\left(O D_{\text {treated }}\right.$ ells / OD untreated cells $\times 100$. The half maximum inhibitory concentration $\left(\mathrm{IC}_{50}\right)$ which represents how much of the extract was needed to reduce metabolic activity by $50 \%$ was derived from GraphPad Prism (V5) using linear regression analysis.

\section{Statistical analysis}

Experiments were all done in triplicate and data was expressed as mean \pm standard deviation. The statistical analyses were performed by oneway analysis of variance and considered to be significantly different at $p<0.05$.

\section{RESULTS AND DISCUSSION}

The phytochemical analysis revealed the biologically active compounds that possess health benefits. The fruit extract contained tannins, flavonoids, alkaloids and saponins (Table 1). It was deficient of steroids. The results were confirmed in another study wherein the presence of almost all the tested phytochemicals were present, except for saponins and steroids from E. ferox leaf extract. ${ }^{21}$ The detected phytochemicals have been reported in literature to possess pharmacological properties that include antibacterial, antioxidant, anti-quorum sensing and cytotoxic activities. ${ }^{29,30}$

GC-MS chromatogram profile of the methanolic fruit extract showed a total of 8 volatile compounds (Table 2 and Figure 1). The major components were cis-Vaccenic acid (87.06\%), 9-Octadecenoic acid, 1,2,3-propanetriyl ester (5.21\%), 4H-Pyran-4-one, 2,3-dihydro-3,5dihydroxy (2.13\%), 9-Hexadecenoic acid $(2.12 \%)$ and Pentadecanoic acid (1.61\%). Other compounds were 10-Octadecenoic acid, methyl ester (0.91\%), Hexadecanoic acid, 2-hydroxy-1-(hydroxym) (0.81\%) and 11, 14-Eicosadienoic acid, methyl ester $(0.18 \%)$. Some of these compounds have been recognised for possession of pharmaceutical properties. cis-Vaccenic acid is an omega-7 fatty acid reported to possess anti-inflammatory, antibacterial and hypolipidemic activities. ${ }^{31}$, ${ }^{32}$ The compound 9-Octadecenoic acid, 1,2,3-propanetriyl ester is an immune modulator with anti-spasmodic activity, ${ }^{33}$ whereas $4 \mathrm{H}$-Pyran4-one, 2,3-dihydro-3,5-dihydroxy-6-methyl has strong antimicrobial, antioxidant, anti-proliferative and anti-inflammatory activities. ${ }^{34}$ 9-Hexadecenoic acid and 10-octadecanoic acid methyl ester are reported to possess antimicrobial effects. ${ }^{35}$ Pentadecanoic acid is an adhesive and sealant compound with protective effects against type 2 diabetes. ${ }^{36}$ The specific biological activity of the fatty acid ester (Hexadecanoic acid, 2-hydroxy-1(hydroxyl methyl) ethyl ester) is unknown. ${ }^{37}$ However, it was assumed that it might have contributed to the profound activities shown by E. ferox fruit extract in this study.

Table 1: Phytochemical constituent analysis $E$. ferox fruit material.

\begin{tabular}{cc}
\hline Phytochemicals & E. ferox fruit material \\
\hline Alkaloids & + \\
Flavonoids & + \\
Glycosides & + \\
Saponins & + \\
Steroids & - \\
Tannins & + \\
\hline
\end{tabular}

Key: + denotes presence and - denotes absence

Table 2: Volatile compounds constituent of $E$. ferox fruit extract.

\begin{tabular}{clc} 
Number & \multicolumn{1}{c}{ Name of compounds } & Area (\%) \\
\hline 1 & 4H-Pyran-4-one, 2,3-dihydro-3,5-dihydroxy-6-methyl & 2.13 \\
2 & 9-Hexadecenoic acid & 2.12 \\
3 & Pentadecanoic acid & 1.59 \\
4 & 11,14-Eicosadienoic acid, methyl ester & 0.18 \\
5 & 10-Octadecenoic acid, methyl ester & 0.91 \\
6 & cis-Vaccenic acid & 87.06 \\
7 & Hexadecanoic acid, 2-hydroxy-1-(hydroxymethyl) ethyl ester & 0.81 \\
8 & 9-Octadecenoic acid, 1,2,3-propanetriyl ester & 5.21 \\
\hline
\end{tabular}




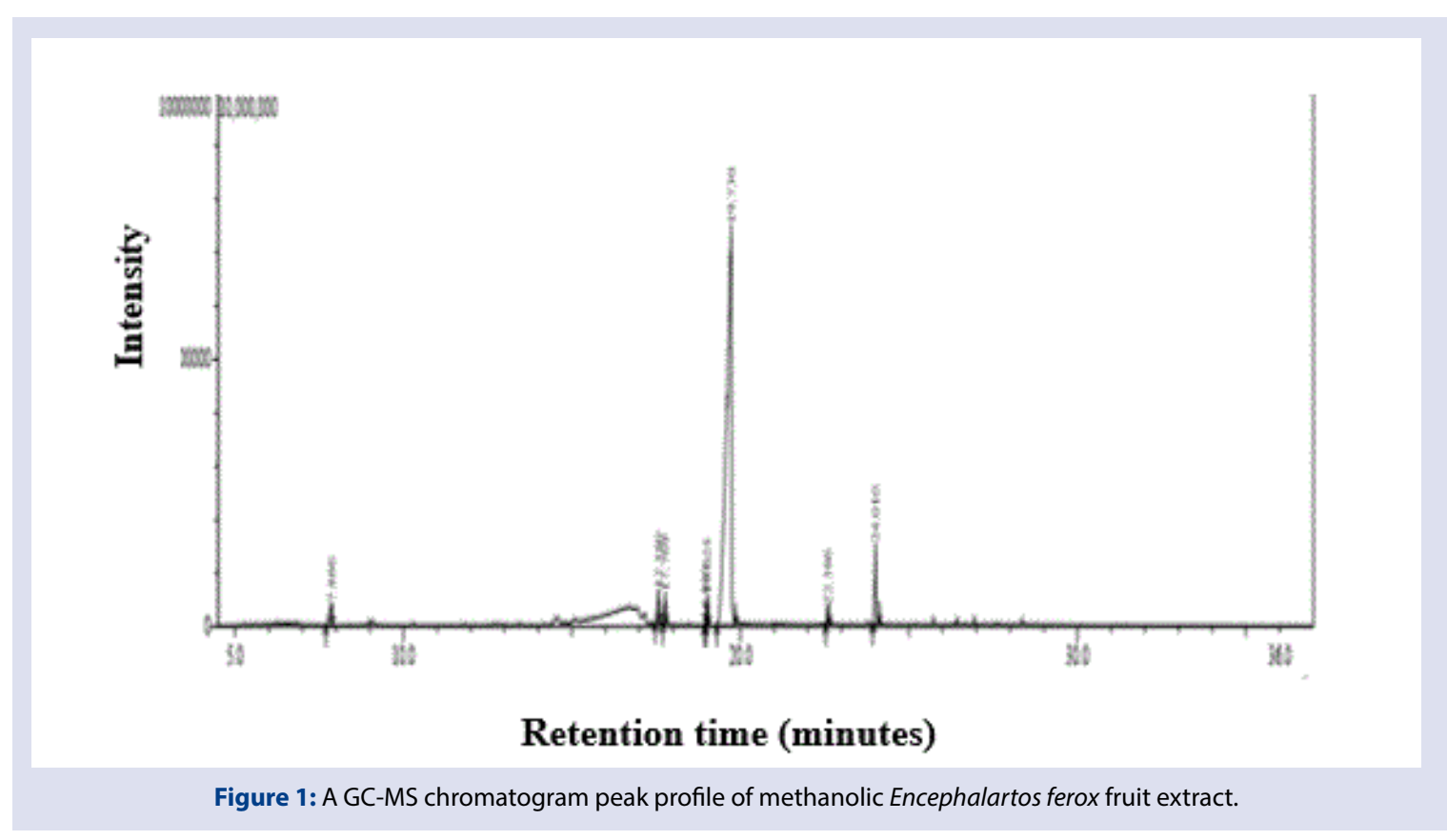

The component 11, 14-Eicosadienoic acid, methyl ester is recognised as a fragrance and flavouring compound. It is also reported to have antioxidant, anti-arthritic, anti-coronary and anti-inflammatory activities. ${ }^{38}$ The presence of these compounds makes E. ferox fruits a source of beneficial bioactive compounds.

\section{Minimum bactericidal concentration (MBC)}

The extract showed broad spectrum of antibacterial activity against all tested strains. S. aureus (ATCC 25923) and B. cereus (ATCC 10102) were the most susceptible strains against the extract with the lowest MIC value of $1.56 \mathrm{mg} / \mathrm{mL}$ (Table 3). P. aeruginosa was the most resistant strain to the extract and had the MIC value of $12.5 \mathrm{mg} / \mathrm{mL}$. Based on the results, Gram positive strains were more sensitive to the extract in comparison to the Gram negative strains. This could be due to the difference in the cell walls of these classes of bacteria. Gram negative bacterial strains are often resistant to most antimicrobial agents due to their outer membrane, which tends to exclude some antimicrobials from penetrating the bacterial cells by acting as a selective barrier. ${ }^{39}$ The extract demonstrated $\mathrm{MBC}$ value greater than $50 \mathrm{mg} / \mathrm{mL}$ against all tested strains. This implied that the extract has only bacteriostatic effect and not bactericidal effect against all tested strains at the utilized concentrations. Nevertheless, the results imply that the extract has potential to be used as health beneficial source of therapeutic antibacterial compounds, especially against Gram positive bacteria. The profound activity of the extract was related to the detected phytochemicals.

\section{Anti-quorum sensing activity}

QS mechanism regulates to bacterial virulence and pathogenicity. ${ }^{31}$ Thus, QS targeting could be an alternative way to control pathogenic bacteria and reduce the prevalence of antimicrobial resistance. The antiQS activity of the fruit extract was investigated against C. violaceium (ATCC 12742). The violacein inhibition was concentration dependant; as the concentration of the extract increased, the violacein production decreased (Figure 2). The extract revealed maximum violacein inhibition of $93 \%$ at $25 \mathrm{mg} / \mathrm{mL}$ and the $\mathrm{IC}_{50}$ value of $0.5 \mathrm{mg} / \mathrm{mL}$. Crude extracts are regarded highly active when their anti-QS activity is $\geq 90 \%$, moderate in the range of $40-89 \%$, and weak when it is $<40 \% .^{40}$ Thus, the cone extract was highly active against violacein production without necessarily inhibiting the growth of C. violaceium (ATCC 12742).
The extract might have exerted anti-QS activity by interrupting AHL synthase, modified AHL or blocked AHL signal receptors. ${ }^{41}$ Anti-QS activity was attributed to the detected phytochemicals, such as tannins. Plant extracts rich in tannins are reported to demonstrate anti-QS activity. ${ }^{42}$

\section{Antioxidants activity}

The antioxidant activity of the extract was evaluated by free radical DPPH and ABTS methods. The extract exhibited maximum DPPH scavenging activity of $80 \%$ at $0.04 \mathrm{mg} / \mathrm{mL}$ and displayed $\mathrm{IC}_{50}$ value of $0.09 \mathrm{mg} / \mathrm{mL}$ (Figure 3). It had a higher $\mathrm{IC}_{50}$ for DPPH compared to $\mathrm{AA}$ and $\mathrm{BHA}$, which both had $\mathrm{IC}_{50}$ value of $0.004 \mathrm{mg} / \mathrm{mL}$. It also demonstrated the highest ABTS scavenging activity of $91 \%$ at 0.005 $\mathrm{mg} / \mathrm{mL}$ with $\mathrm{IC}_{50}$ value of $0.003 \mathrm{mg} / \mathrm{mL}$ (Figure 3). Its $\mathrm{IC}_{50}$ on ABTS scavenging activity was lower than those of AA ( $\mathrm{IC}_{50}=0.03 \mathrm{mg} / \mathrm{mL}$ ) and BHA ( $\mathrm{IC}_{50}=0.05 \mathrm{mg} / \mathrm{mL}$ ). Molyneux classified antioxidant activity where the highly active compounds have $\mathrm{IC}_{50}$ values $<0.05 \mathrm{mg} / \mathrm{mL}$, the active category have $\mathrm{IC}_{50}$ values of $0.05-0.1 \mathrm{mg} / \mathrm{mL}$, medium category have $\mathrm{IC}_{50}$ values of $0.1-0.15 \mathrm{mg} / \mathrm{mL}$, and weak categories have $\mathrm{IC}_{50}$ values of $0.151-0.2 \mathrm{mg} / \mathrm{mL}^{43}$ Thus, the fruit extract is highly effective against ABTS radicals and active for DPPH radicals. The pronounced antioxidant activity of the extract, especially on ABTS radicals was attributed to the synergistic action of the detected bioactive compounds within the extract. Thus, the displayed scavenging activity suggested that the extract has good potent ABTS and DPPH scavenging activity and should be explored as novel source of antioxidant compounds. The results were confirmed in another study wherein methanolic leaf extract of $E$. ferox displayed good antioxidant activities for DPPH and ABTS. $^{21}$

\section{Cytotoxicity of the extract}

The employment of in vitro cytotoxicity and cell viability assays is important in toxicology and pharmacology, in order to evaluate the effects of chemicals on cell health. ${ }^{44}$ The MTT assay that measures the reduction of MTT salt to formazan by healthy cells was used to evaluate cell viability. Untreated control cells have a viability of $100 \%$ (Figure 4). After treatment with low dose of the $E$ forex, cell viability was increased (Figure 4) indicating stimulation of metabolism. The highest viability (118\%) occurred between $250-750 \mu \mathrm{g} / \mathrm{mL}$, but returned to $\pm 100 \%$ at $2000 \mu \mathrm{g} / \mathrm{mL}$. Subsequent increases in concentration of the extract 
Table 3: Minimum inhibitory concentration and minimum bactericidal concentration of the extract.

\begin{tabular}{ccccc}
\hline Bacteria & \multicolumn{2}{c}{ Extract } & \multicolumn{2}{c}{ Ciprofloxacin } \\
\cline { 2 - 5 } & $\begin{array}{c}\text { MIC } \\
(\mathrm{mg} / \mathrm{mL})\end{array}$ & $\begin{array}{c}\mathrm{MBC} \\
(\mathrm{mg} / \mathrm{mL})\end{array}$ & $\begin{array}{c}\text { MIC } \\
(\mathrm{mg} / \mathrm{mL})\end{array}$ & $\begin{array}{c}\mathrm{MBC} \\
(\mathrm{mg} / \mathrm{mL})\end{array}$ \\
\hline S. aureus (ATCC 25923) & $1.56 \pm 0$ & $>50 \pm 0$ & $25 \pm 0$ & $>50 \pm 0$ \\
B. cereus (ATCC 10102) & $1.56 \pm 0$ & $>50 \pm 0$ & $25 \pm 0$ & $>50 \pm 0$ \\
E. coli (ATCC 25922) & $6.25 \pm 0$ & $>50 \pm 0$ & $25 \pm 0$ & $>50 \pm 0$ \\
P. aeruginosa (ATCC 27853) & $12.5 \pm 0$ & $>50 \pm 0$ & $25 \pm 0$ & $>50 \pm 0$ \\
\hline
\end{tabular}

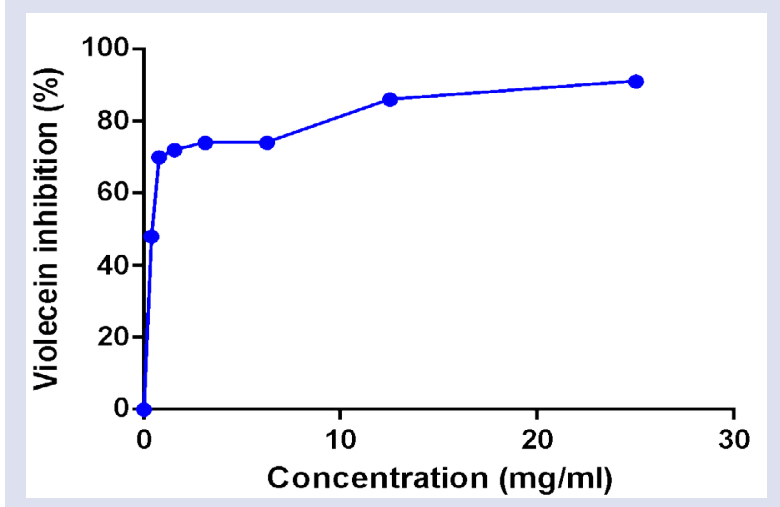

Figure 2: Anti-quorum sensing activity of the fruit extract against C. violaceium (ATCC 12742).
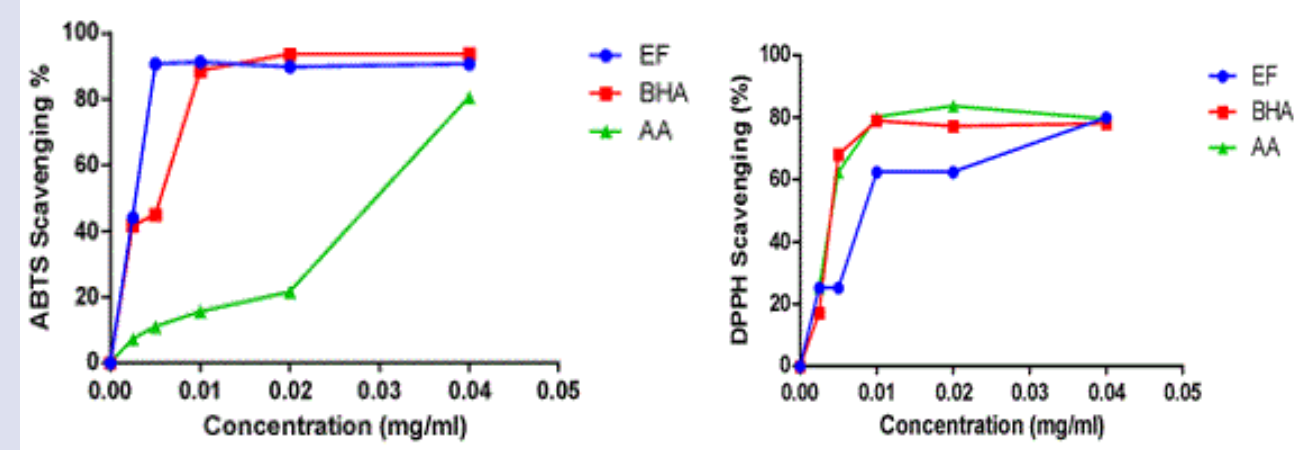

Figure 3. ABTS scavenging activities of the extract, BHA and AA (left) and DPPH scavenging activities of the extract, BHA and AA (right). EF denotes extract, BHA denotes butylated hydroxyl anisole and AA denotes ascorbic acid.

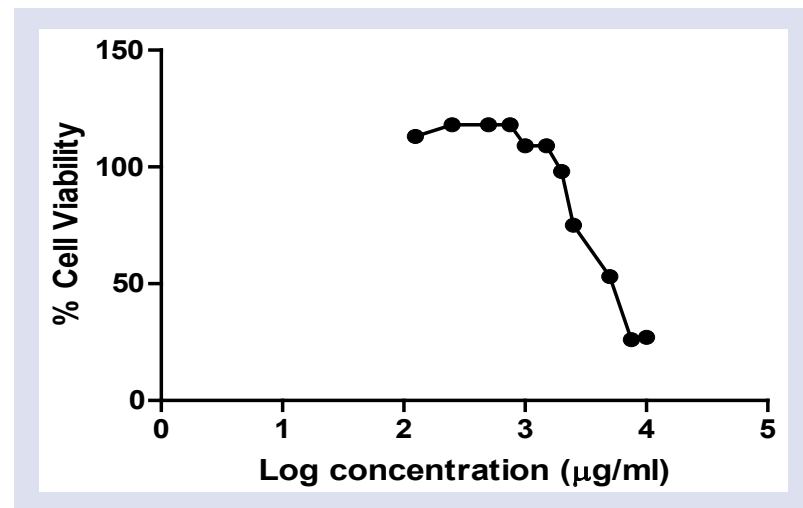

Figure 4: Cytotoxic activity of the methanolic $E$. ferox fruit extract against HepG2 liver carcinoma cells at different concentrations. Following an initial increase in cell viability relative to the control, a dose-dependent decrease in viability was obtained with subsequent increases in concentration of the extract. 
$(2500-5000 \mu \mathrm{g} / \mathrm{mL})$ induced consecutive decreases in cell viability until the lowest viability of $\pm 26 \%$ was reached $(7500-10000 \mu \mathrm{g} / \mathrm{mL})$, suggesting that the $E$ forex phytochemicals are cytotoxic to HepG2 cells at these concentrations. The $\mathrm{IC}_{50}$ obtained was $5370 \mu \mathrm{g} / \mathrm{mL}$; it is at this concentration that metabolic activity was inhibited by $50 \%$. Thus, succinate dehydrogenase reduction of MTT salt using NADH for reducing power was decreased. ${ }^{44}$ Succinate dehydrogenase forms part of complex II of the electron transport chain and is therefore an important contributor to electron transfer necessary for ATP production. When ATP concentration is reduced, cells die with the mode of cell death dependent on the severity of ATP depletion. The result suggests that mitochondrial activity and ATP production was inhibited by more than $25 \%$ at concentrations above $2500 \mu \mathrm{g} / \mathrm{mL}$ (Figure 4 ), and indicates that these concentrations negatively impact cell function and would therefore not be safe as an antibacterial therapeutic intervention for gram negative bacteria. It further illustrates that the extracts could be safely used as an antioxidant source, as the cytotoxic $\mathrm{IC}_{50}$ is several fold higher than the concentration range that yields significant antioxidant scavenging ability.

\section{CONCLUSION}

The methanol extract revealed the presence of most screened phytochemicals. It exhibited antibacterial activity against all tested strains with minimum inhibitory concentration range of $1.56-12.5$ $\mathrm{mg} / \mathrm{mL}$. It demonstrated DPPH and ABTS scavenging activities with low $\mathrm{IC}_{50}$ values of $0.09 \mathrm{mg} / \mathrm{mL}$ and $0.003 \mathrm{mg} / \mathrm{mL}$, respectively. It showed strong anti-quorum sensing activity by inhibiting violacein production by $93 \%$ at $25 \mathrm{mg} / \mathrm{mL}$. It also demonstrated safety for use at concentrations lower than $2500 \mu \mathrm{g} / \mathrm{mL}$. The profound biological activities were attributed to the detected phytochemicals. Thus, the extract has potential to be used as health beneficial source of non-toxic therapeutic compounds. For future study, in silico, in vitro and in vivo investigations of the individual phytochemicals are essential.

\section{ACKNOWLEDGEMENTS}

The Authors are grateful to the National Research Foundation of South Africa and the University of Zululand for providing financial support and necessary laboratory facilities.

\section{CONFLICTS OF INTEREST}

The authors declare/ no conflicts of interest.

\section{ABBREVIATIONS}

DMSO: dimethyl sulfoxide; DPPH: 2.2-diphenyl-1-picrylhydrazyl; ABTS: 2,21- Azino-bis (3-ethylbenzthiazoline-6-sulfonic acid); MTT: 3-(4,5-Dimethylthiazol-2-yl)-2,5diphenyltetrazolium bromide; rpm: revolution per minute; INT: $\mathrm{p}$-iodonitrotetrazolium violet; $\mathrm{IC}_{50}$ : median inhibitory concentration; $\mu \mathrm{g} / \mathrm{mL}$ : microgram/milliliter; g: gram; $\mathrm{mL}$ : millimeter; ${ }^{\circ} \mathrm{C}$ : degree Celsius; $\mu \mathrm{L}$ : microliter; \%: percent; AA: ascorbic acid; BHA: butylated hydroxyl anisole; EF: extract; GC-MS: gas chromatography-mass spectrometry; GC: gas chromatography; MS: mass spectrometry; MIC: minimum inhibitory concentration; $M B C$ : minimum bactericidal concentration; QS: quorum sensing; v: volume; E. ferox: Encephalartos ferox; S. aureus: Staphylococcus aureus; B. cereus: Bacillus cereus; E. coli: Escherichia coli; P. aeruginosa: Pseudomonas aeruginosa; ATCC: American Type Culture Collection.

\section{REFERENCES}

1. Humphreys G, Fleck F. United Nations meeting on antimicrobial resistance. World Health Organization. Bulletin of the World Health Organization. 2016;94:638

2. Srivastava J, Chandra H, Nautiyal AR, Kalra SJ. Antimicrobial resistance (AMR) and plant-derived antimicrobials (PDA $\mathrm{m} \mathrm{s}$ ) as an alternative drug line to control infections. 3 Biotech. 2014:4:451-60.
3. Agyare C, Boamah VE, Zumbi CN, Osei FB. Antibiotic use in poultry production and its effects on bacterial resistance. Antimicrobial Resistance-A Global Threat: IntechOpen; 2018.

4. Hwang $A Y$, Gums JG. The emergence and evolution of antimicrobial resistance: Impact on a global scale. Bioorganic \& Medicinal Chemistry. 2016;24:6440-5

5. Iqbal J, Zaib S, Farooq U, Khan A, Bibi I, Suleman S. Antioxidant, Antimicrobial and free radical scavenging potential of aerial parts of Periploca aphylla and Ricinus communis. ISRN pharmacology. 2012;2012.

6. Organization WH. Traditional Medicine Strategy 2002-2005. 2002 (WHO/ EDM/TRM/2002.1). Online document at: http://www. who. int/medicines/ publications/traditional/policy/en/(accessed January 16, 2016).

7. Yuan $\mathrm{H}, \mathrm{Ma} \mathrm{Q}, \mathrm{Ye} \mathrm{L}$, Piao $\mathrm{G}$. The traditional medicine and modern medicine from natural products. Molecules. 2016;21:559.

8. Eloff J, Katerere D, McGaw L. The biological activity and chemistry of the southern African Combretaceae. Journal of Ethnopharmacology. 2008;119:68699.

9. Das K, Tiwari R, Shrivastava D. Techniques for evaluation of medicinal plant products as antimicrobial agent: Current methods and future trends. Journal of Medicinal Plants Research. 2010;4:104-11.

10. Dowling A, O'Dwyer J, Adley C. Antibiotics: mode of action and mechanisms of resistance. Formatex Research Center: Badajoz, Spain. 2017:536-45.

11. Van Vuuren S, Holl D. Antimicrobial natural product research: a review from a South African perspective for the years 2009-2016. Journal of Ethnopharmacology. 2017;208:236-52

12. Fuqua C, Parsek MR, Greenberg EP. Regulation of gene expression by cell-tocell communication: acyl-homoserine lactone quorum sensing. Annual review of genetics. 2001;35:439-68.

13. Li Z, Nair SK. Quorum sensing: how bacteria can coordinate activity and synchronize their response to external signals? Protein Science. 2012;21:140317.

14. Priscilia B, Novita H, Elya B. Antioxidant and antibacterial assay against fish pathogen bacteria of Kjellbergiodendron celebicum (Koord.) Merr. leaf extract. Pharmacognosy Journal. 2020;12.

15. Ahmed AS, Elgorashi EE, Moodley N, McGaw LJ, Naidoo V, Eloff JN. The antimicrobial, antioxidative, anti-inflammatory activity and cytotoxicity of different fractions of four South African Bauhinia species used traditionally to treat diarrhoea. Journal of Ethnopharmacology. 2012;143:826-39.

16. Lobo V, Patil A, Phatak A, Chandra N. Free radicals, antioxidants and functional foods: Impact on human health. Pharmacognosy Reviews. 2010;4:118.

17. Xu D-P, Li Y, Meng X. Natural antioxidants in foods and medicinal plants: Extraction, assessment and resources. International Journal of Molecular Sciences. 2017;18:96.

18. Maliehe TS, Shandu JS, Basson AK, Simelane MB, Lazarus G, Singh M Pharmacodynamic and cytotoxicity effects of Syzygium cordatum \{S Ncik, 48 (UZ)\} fruit-pulp extract in gastrointestinal tract infections. Tropical Journal of Pharmaceutical Research. 2017;16:1349-55.

19. Vorster P. Classification concepts in Encephalartos (Zamiaceae). Cycad Classification: Concepts and Recommendations. CABI, Wallingford, United Kingdom. 2004:69-83.

20. Cousins S, Williams V, Witkowski E. Sifting through cycads: A guide to identifying the stem fragments of six South African medicinal Encephalartos species. South African Journal of Botany. 2013;84:115-23.

21. Ojo MC, Osunsanmi FO, Zaharare GE. In-vitro Anti-diabetic and Antioxidant Efficacy of Methanolic Extract of Encephalartos ferox leaves. Pharmacognosy Journal. 2019;11.

22. Harborne A. Phytochemical methods a guide to modern techniques of plant analysis: springer science \& business media; 1998

23. Wibowo DP, Mariani R, Hasanah SU, Aulifa DA. Chemical constituents, antibacterial activity and mode of action of Elephant ginger (Zingiber officinale var. officinale) and Emprit ginger rhizome (Zingiber officinale var. amarum) essential oils. Pharmacognosy Journal. 2020;12:404-9.

24. Eloff JN. A sensitive and quick microplate method to determine the minimal inhibitory concentration of plant extracts for bacteria. Planta Medica. 1998;64:711-3

25. Chenia HY. Anti-quorum sensing potential of crude Kigelia africana fruit extracts Sensors. 2013;13:2802-17.

26. Brand-Williams W, Cuvelier M-E, Berset $C$. Use of a free radical method to evaluate antioxidant activity. LWT-Food science and Technology. 1995;28:25-30.

27. Re R, Pellegrini N, Proteggente A, Pannala A, Yang M, Rice-Evans C. Antioxidant activity applying an improved ABTS radical cation decolorization assay. Free Radical Biology and Medicine. 1999;26:1231-7.

28. Mosmann T. Rapid colorimetric assay for cellular growth and survival: application to proliferation and cytotoxicity assays. Journal of immunological methods. 1983;65:55-63. 
29. Cowan MM. Plant products as antimicrobial agents. Clinical microbiology reviews. 1999;12:564-82.

30. Shukla V, Bhathena Z. Broad spectrum anti-quorum sensing activity of tanninrich crude extracts of indian medicinal plants. Scientifica. 2016;2016.

31. Hussein HM, Hameed IH, Ibraheemr OA. Antimicrobial activity and spectral chemical analysis of methanolic leaves extract of Adiantum capillus-veneris using GC-MS and FTIR spectroscopy. International Journal of Pharmacognosy and Phytochemical Research. 2016;8:369-85.

32. Semwal P, Painuli S, Badoni H, Bacheti RK. Screening of phytoconstituents and antibacterial activity of leaves and bark of Quercus leucotrichophora A. Camus from Uttarakh and Himalaya. Clinical Phytoscience. 2018;4:30.

33. Al-Marzoqi AH, Hadi MY, Hameed IH. Determination of metabolites products by Cassia angustifolia and evaluate antimicobial activity. Journal of Pharmacognosy Phytotheraphy. 2016;8:25-48.

34. Swamy MK, Sinniah UR, Akhtar MS. In vitro pharmacological activities and GCMS analysis of different solvent extracts of Lantana camara leaves collected from Tropical Region of Malaysia. Evidence-Based Complementary and Alternative Medicine. 2015;2015.

35. Rahman MM, Ahmad SH, Mohamed MTM, AbRahman MZ. Antimicrobial compounds from leaf extracts of Jatropha curcas, Psidium guajava, and Andrographis paniculata. The Scientific World Journal. 2014;2014.

36. Hellgreen LI, Nordby P. Bioactive lipids in dairy fat. In dairy in human health and diseases across lifespan. Academic Press. 2017;233-7.
37. Padmashree MS, Roopa B, Ashwathanarayana R, Raja N. Antibacterial properties of Ipomoea staphylina Roem \& Schult. plant extracts with comparing its preliminary qualitative phytochemical and quantitative GC-MS analysis. Tropical Plant Research. 2018;5:349-69.

38. Kandhasamy M, Chinnasamy PS, Parimala S. Phytochemical evaluation of seed and fruit pulp extracts of Passiflora foetida $L$. World Journal of Pharmaceutical Research. 2018;7:1924-32.

39. Uche-Okereafor N, Sebola T, Tapfuma K, Mekuto L, Green E, Mavumengwana $V$. Antibacterial activities of crude secondary metabolite extracts from Pantoea species obtained from the stem of Solanum mauritianum and their effects on two cancer cell lines. International Journal of Environmental Research and Public Health. 2019;16:602.

40. Baloyi I, Cosa S, Combrinck S, Leonard CM, Viljoen AM. Anti-quorum sensing and antimicrobial activities of South African medicinal plants against uropathogens. South African Journal of Botany. 2019;122:484-91.

41. Manner S, Fallarero A. Screening of natural product derivatives identifies two structurally related flavonoids as potent quorum sensing inhibitors against gramnegative bacteria. International Journal of Molecular Sciences. 2018;19:1346.

42. Erhabor C, Erhabor J, McGaw L. The potential of South African medicinal plants against microbial biofilm and quorum sensing of foodborne pathogens: A review. South African Journal of Botany. 2019.

43. Molyneux P. The use of the stable free radical diphenylpicrylhydrazyl (DPPH) for estimating antioxidant activity. Songklanakarin J sci Technol. 2004;26:211-9

44. Tolosa L, Donato MT, Gómez-Lechón MJ. General Cytotoxicity Assessment by Means of the MTT Assay. Methods Mol Biol. 2015;1250:333-48.

\section{GRAPHICAL ABSTRACT}
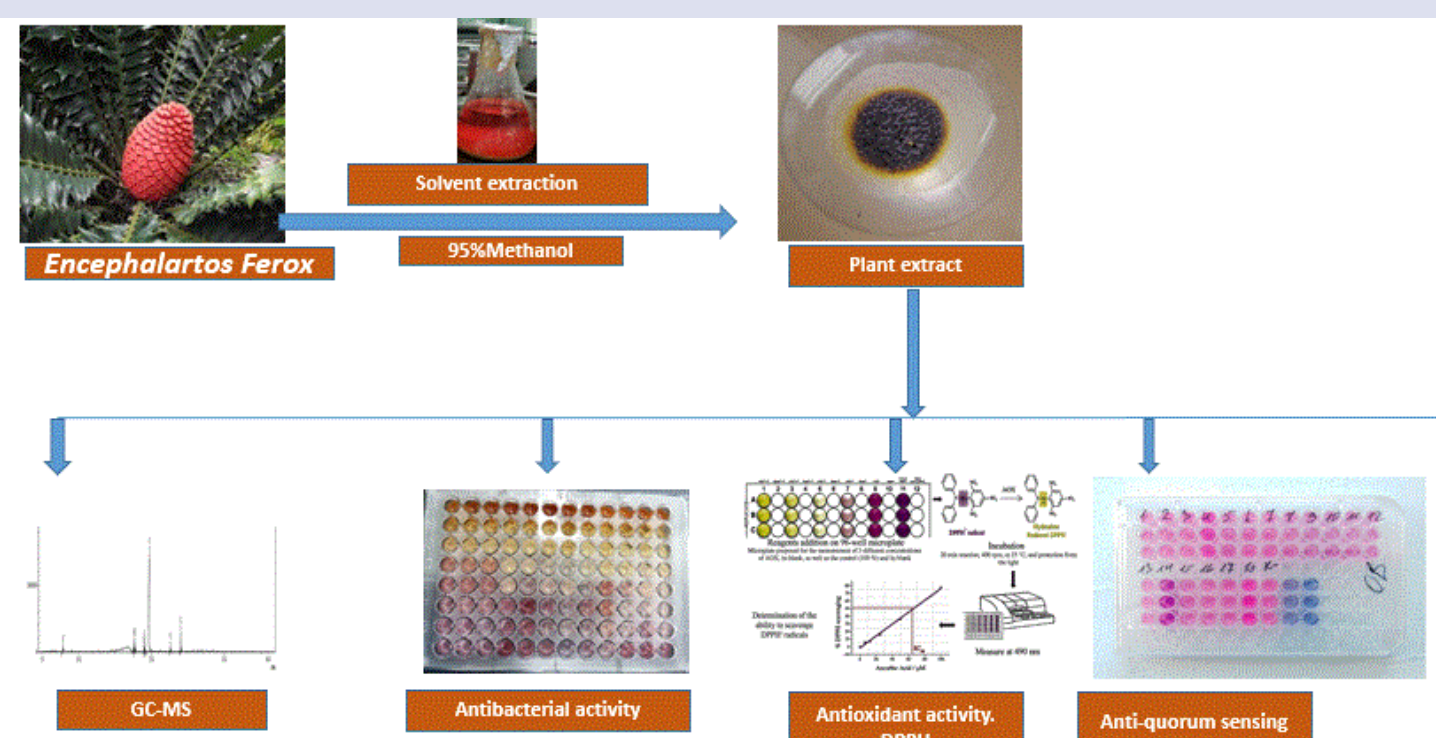

Anti-quorum sensing

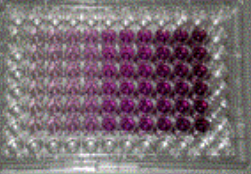

Cytotoxicity

\section{ABOUT AUTHORS}

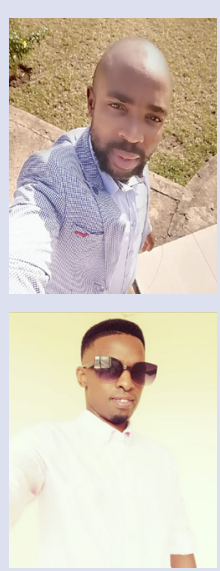

\section{Mr PHTsilo}

$\mathrm{He}$ is holding an Honours degree in Microbiology from the University of Zululand. He is currently working on his MSc in Microbiology in the same institution.

\section{DrTS Maliehe}

He holds a PhD in Microbiology from the University of Zululand. He is currently a postdoctoral fellow in the same institution. 


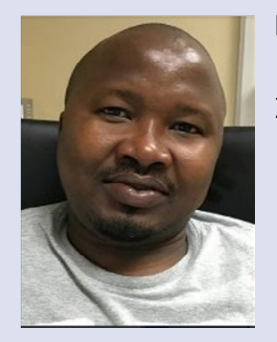

\section{Mr JS Shandu}

$\mathrm{He}$ is a lecturer at the University of Zululand. He holds MSc in Microbiology which was obtained from the University of

Zululand. He has a lot of publications in different peer review journals.

Cite this article:Tsilo PH, ST Maliehe, Shandu JS, Khan R. Chemical Composition and Some Biological Activities of the Methanolic Encephalartos ferox Fruit Extract. Pharmacogn J. 2020;12(5):1190-7. 